\title{
Short term significance of DNA ploidy and cell proliferation in breast carcinoma: a multivariate analysis of prognostic markers in a series of 308 patients
}

António E Pinto, Saudade André, Jorge Soares

\begin{abstract}
Aim-To determine the importance of tumour DNA ploidy and cell proliferation, as measured by the $S$ phase fraction (SPF), in relation to other established clinicopathological indicators of prognosis in breast cancer.
\end{abstract}

Methods-A prospective study of 308 patients. Tumours were staged following the TNM system criteria and were classified according to the histological type and grade. DNA flow cytometry was performed on fresh/frozen samples stained with propidium iodide. Hormone receptors were analysed by immunocytochemistry. A Cox proportional hazards regression model was used for statistical evaluation of the prognostic factors.

Results-Median follow up time was $\mathbf{3 9 . 6}$ months (range 3 to 84). A DNA diploid pattern was found in 134 tumours $(43.5 \%)$ and aneuploid in 174 (56.5\%). Median SPF value was $6.1 \%$ (range $1 \%$ to $27.8 \%$ ). DNA ploidy and SPF were strongly correlated $(p<0.001)$, and both were related to histological type $(p<0.001)$, grade of differentiation $(p<0.001)$, tumour size $(p=0.006$ and $p=0.002)$, and hormone receptor activity $(p<0.001)$. DNA ploidy was also related to node status $(p=0.022)$, but SPF was not. In univariate analysis, there were significant correlations between disease-free survival and age, histological grade, tumour size, node status, DNA ploidy, SPF, and hormone receptor activity; age, tumour size, node status, DNA ploidy, and hormone receptors were predictors of overall survival. In multivariate analysis, only node status $(p=0.001)$ and DNA ploidy $(p=0.006)$ retained independent prognostic significance in relation with overall survival, while node status $(p<0.001)$ and SPF $(p<0.001)$ were predictors of disease-free survival. DNA ploidy and SPF continued to predict disease-free and overall survival in lymph node positive (pN1) patients but not in the lymph node negative (pN0) group.

Conclusions-DNA ploidy and SPF are strongly intercorrelated and have independent prognostic value for predicting the short term clinical outcome of breast carcinoma patients. (f Clin Pathol 1999;52:604-611)
Keywords: DNA ploidy; S phase fraction; flow cytometry; breast carcinoma; prognosis

The clinicopathological features currently used to assess prognosis in breast cancer often fail to characterise the clinical heterogeneity of the disease accurately, particularly with respect to predicting tumour behaviour in the individual case. $^{12}$ In recent years, therefore, many attempts have been made in several areas, including analytical cytology, immunocytochemistry, and molecular biology, to identify features that could be clinically useful in assessing prognosis. ${ }^{3}$

The predictive role of DNA flow cytometry in patients with breast carcinoma has been investigated in many studies. In some it was concluded that DNA ploidy and S phase fraction (SPF) were useful in predicting clinical outcome, ${ }^{4-10}$ and in particular it has often been claimed that SPF has independent prognostic value. ${ }^{11-17}$ In contrast, other studies showed that flow cytometry data analysis provides no additional prognostic information. ${ }^{18-21}$

It is generally accepted that most of the controversy over these results stems from the different methods and criteria used in the various studies. ${ }^{22}$ Besides intratumour heterogeneity, ${ }^{2324}$ confounding factors include patient selection bias, differences in treatment, insufficient numbers of patients, and differences in the type of sample used (fresh $v$ paraffin embedded), the tissue processing procedures, and the criteria used for interpreting the histograms. ${ }^{2225}$

Despite the methodological drawbacks, investigations have continued in this area, mainly in lymph node negative breast cancer patients, aiming to identify those at highest risk of disease recurrence who might benefit from additional postsurgical systemic treatment. This approach avoids submitting relatively low risk patients to the toxic effects of adjuvant therapy, and improves the cost/benefit ratio of the treatment.

Our aim in this study was to investigate the predictive value of DNA flow cytometry in breast carcinoma, applying some recently developed methods for DNA histogram interpretation such as corrections for sliced nuclei debris and aggregates, and following three methodological steps: (1) to evaluate the correlation between DNA content (ploidy) and $S$ phase fraction (cell proliferation) and other established prognostic factors in a series
Accepted for publication 29 April 1999 
Table 1 Clinicopathological characteristics of breast cancer patients and correlation with flow cytometric variables

\begin{tabular}{|c|c|c|c|c|c|c|c|c|}
\hline \multirow[b]{2}{*}{ Characteristics } & \multicolumn{4}{|c|}{ Ploidy (\%) } & \multicolumn{4}{|c|}{$S P F(\%)$} \\
\hline & $n$ & Diploid & Aneuploid & $p$ Value & $n$ & $<6.1 \%$ & $\geqslant 6.1 \%$ & $p$ Value \\
\hline \multicolumn{4}{|l|}{ Age } & 0.224 & & & & 0.717 \\
\hline$<50$ years & 82 & 37.8 & 62.2 & & 63 & 47.6 & 52.4 & \\
\hline$\geqslant 50$ years & 226 & 45.6 & 54.4 & & 175 & 50.3 & 49.7 & \\
\hline \multicolumn{4}{|l|}{ Histological type } & $<0.001$ & & & & $<0.001$ \\
\hline Ductal & 275 & 38.5 & 61.5 & & 207 & 44.4 & 55.6 & \\
\hline Others & 33 & 84.8 & 15.2 & & 31 & 83.9 & 16.1 & \\
\hline \multicolumn{4}{|l|}{ Grade } & $<0.001$ & & & & $<0.001$ \\
\hline G1 & 86 & 67.4 & 32.6 & & 77 & 68.8 & 31.2 & \\
\hline G2 & 140 & 43.6 & 56.4 & & 101 & 53.5 & 46.5 & \\
\hline G3 & 82 & 18.3 & 81.7 & & 60 & 18.3 & 81.7 & \\
\hline \multicolumn{4}{|l|}{ Tumour size } & 0.006 & & & & 0.002 \\
\hline pT1 & 120 & 54.2 & 45.8 & & 89 & 62.9 & 37.1 & \\
\hline pT2 & 165 & 38.2 & 61.8 & & 132 & 43.9 & 56.1 & \\
\hline pT3 & 23 & 26.1 & 73.9 & & 17 & 23.5 & 76.5 & \\
\hline \multicolumn{4}{|l|}{ Node status } & 0.022 & & & & 0.493 \\
\hline pNo & 175 & 49.1 & 50.9 & & 142 & 51.4 & 48.6 & \\
\hline $\mathrm{pN} 1$ & 133 & 36.1 & 63.9 & & 96 & 46.9 & 53.1 & \\
\hline \multicolumn{4}{|c|}{ Oestrogen receptors } & $<0.001$ & & & & $<0.001$ \\
\hline Positive & 229 & 52.4 & 47.6 & & 185 & 58.9 & 41.1 & \\
\hline Negative & 78 & 17.9 & 82.1 & & 52 & 17.3 & 82.7 & \\
\hline \multicolumn{4}{|c|}{ Progesterone receptors } & $<0.001$ & & & & $<0.001$ \\
\hline Positive & 188 & 54.8 & 45.2 & & 156 & 60.3 & 39.7 & \\
\hline Negative & 119 & 26.0 & 74.0 & & 81 & 29.6 & 70.4 & \\
\hline
\end{tabular}

SPF, S phase fraction.

of breast carcinomas using fresh/frozen material; (2) to analyse the impact of this DNA information in the short term on disease-free survival and overall survival after primary surgical treatment; and (3) to determine the independent prognostic value of the two flow cytometric variables along with the other factors using a multivariate model, in order to identify subgroups of breast cancer patients who might be at low or high risk for tumour recurrence.

Table 2 Kaplan-Meier five year survival estimates of breast cancer patients by clinicopathological and cytometric characteristics

\begin{tabular}{|c|c|c|c|c|c|}
\hline \multirow[b]{2}{*}{ Characteristic } & \multirow[b]{2}{*}{$n$} & \multicolumn{2}{|c|}{ Disease-free survival } & \multicolumn{2}{|l|}{ Overall survival } \\
\hline & & $\% 5$ years $(S D)$ & $p$ Value & $\% 5$ years $(S D)$ & $p$ Value \\
\hline \multicolumn{2}{|l|}{ Age } & & \multirow[t]{3}{*}{0.006} & & \multirow[t]{3}{*}{0.048} \\
\hline$<50$ years & 82 & $66.8(0.072)$ & & $70.5(0.076)$ & \\
\hline$\geqslant 50$ years & 226 & $82.6(0.039)$ & & $83.9(0.044)$ & \\
\hline \multicolumn{2}{|c|}{ Histological type } & & \multirow[t]{3}{*}{0.211} & & \multirow[t]{3}{*}{0.624} \\
\hline Ductal & 275 & $76.3(0.040)$ & & $78.6(0.043)$ & \\
\hline \multirow{2}{*}{\multicolumn{2}{|c|}{ Grade }} & $90.9(0.050)$ & & $89.9(0.056)$ & \\
\hline & & & \multirow[t]{4}{*}{$<0.002$} & & \multirow[t]{4}{*}{0.044} \\
\hline G1 & 86 & $94.0(0.026)$ & & $93.5(0.035)$ & \\
\hline G2 & 140 & $73.5(0.066)$ & & $77.3(0.062)$ & \\
\hline G3 & 82 & $66.5(0.085)$ & & $68.5(0.097)$ & \\
\hline \multicolumn{2}{|l|}{ Tumour size } & & \multirow[t]{4}{*}{0.041} & & \multirow[t]{4}{*}{0.030} \\
\hline pT1 & 120 & $78.5(0.075)$ & & $92.8(0.030)$ & \\
\hline pT2 & 165 & $78.7(0.036)$ & & $77.4(0.052)$ & \\
\hline pT3 & 23 & $68.8(0.098)$ & & $51.9(0.160)$ & \\
\hline \multicolumn{2}{|l|}{ Node status } & & \multirow[t]{3}{*}{$<0.001$} & & \multirow[t]{3}{*}{$<0.001$} \\
\hline pNo & 175 & $87.5(0.049)$ & & $91.0(0.032)$ & \\
\hline pN1 & 133 & $66.4(0.046)$ & & $65.7(0.075)$ & \\
\hline \multicolumn{2}{|c|}{ DNA ploidy (A) } & & \multirow[t]{3}{*}{$<0.001$} & & \multirow[t]{3}{*}{0.001} \\
\hline Diploid & 134 & $88.5(0.050)$ & & $93.8(0.027)$ & \\
\hline Aneuploid & 174 & $69.5(0.049)$ & & $69.9(0.059)$ & \\
\hline \multicolumn{2}{|c|}{ DNA ploidy (B) } & & \multirow[t]{4}{*}{$<0.001$} & & \multirow[t]{4}{*}{$<0.001$} \\
\hline Diploid & 134 & $88.5(0.050)$ & & $93.8(0.027)$ & \\
\hline $\mathrm{hd}+\mathrm{t}$ & 145 & $69.4(0.056)$ & & $73.4(0.063)$ & \\
\hline $\mathrm{m}+\mathrm{ht}$ & 29 & $70.9(0.088)$ & & $54.7(0.150)$ & \\
\hline \multicolumn{2}{|l|}{ SPF } & & \multirow[t]{3}{*}{$<0.001$} & & \multirow[t]{3}{*}{$<0.001$} \\
\hline$<6.1 \%$ & 118 & $89.5(0.055)$ & & $97.4(0.015)$ & \\
\hline$\geqslant 6.1 \%$ & 120 & $69.0(0.062)$ & & $70.0(0.070)$ & \\
\hline \multicolumn{2}{|c|}{ Oestrogen receptors } & & 0.035 & & 0.039 \\
\hline Positive & 229 & $81.7(0.037)$ & & $80.7(0.048)$ & \\
\hline Negative & 78 & $68.4(0.086)$ & & $78.5(0.059)$ & \\
\hline Progesterone & tors & & 0.024 & & 0.018 \\
\hline Positive & 188 & $82.2(0.043)$ & & $84.7(0.045)$ & \\
\hline Negative & 119 & $72.3(0.060)$ & & $72.8(0.068)$ & \\
\hline
\end{tabular}

$\mathrm{hd}+\mathrm{t}$, hyperdiploid + tetraploid; $\mathrm{m}+\mathrm{ht}$, multiploid + hypertetraploid; SPF, S phase fraction.

\section{Methods}

CLINICOPATHOLOGICAL DATA

The study involved 308 women with operable breast cancer diagnosed and treated at Instituto Português de Oncologia-Lisbon Centre, between 1991 and 1996, and for whom tumour samples for flow cytometry and follow up data were available. The mean age of the patients was 58.5 years (range 23 to 88 years). For the histopathological study, routinely stained slides were used (haematoxylin and eosin). The histological type and the tumour staging of breast carcinomas were evaluated using the TNM-UICC system. ${ }^{26}$ The whole series included 275 invasive ductal carcinomas $(89.3 \%)$ and 33 breast carcinomas of other histological types $(10.7 \%)-11$ lobular, 11 mucinous, four papillary, two apocrine, two tubular, two medullary, and one metaplastic. At least 10 axillary lymph nodes were examined in each case. Tumour differentiation was assessed using the Elston and Ellis grading system. ${ }^{27}$ The clinicopathological characteristics of the patients are summarised in table 1 .

Two hundred and eighty patients were treated by modified radical mastectomy and axillary lymphadenectomy, while 28 received conservative treatment (tumorectomy or quadrantectomy) and axillary lymph node dissection. Following the guidelines established in our institution, adjuvant chemotherapy with cyclophosphamide, methotrexate, and 5-fluorouracil (CMF) was given to all node positive premenopausal patients and hormone receptor negative postmenopausal patients, and to node negative patients with high risk tumour recurrence criteria (tumour size greater than $2 \mathrm{~cm}$, poor differentiation, and lack of hormone receptor expression) $(n=132)$. Endocrine treatment with tamoxifen was given to all hormone receptor positive postmenopausal patients $(n=127)$. Local radiotherapy was given postoperatively to the patients treated with conservative breast surgery $(n=28)$, while in lymph node positive patients radiotherapy was given to the axillary region $(n=133)$. The patients were followed up every four months for the first year, at least every six months for the next four years, and at intervals of 12 months thereafter. Their routine evaluation included clinical examination and laboratory tests, mammography every year, and chest $x$ rays, liver ultrasound, and bone scans whenever clinically indicated.

Information on survival (disease-free survival and overall survival) was obtained from review of clinical records or consultation with an epidemiological registry service at our institution (ROR-Sul), or through written or telephone correspondence with the patients or relatives. Disease-free survival was defined as the interval between surgical resection and the first recurrence or metastasis. Duration of follow up was calculated as the time elapsed between primary surgery and the most recent clinical observation (or death). One patient $(0.3 \%)$ who died from an unrelated cause was censored from the survival analysis. 
A

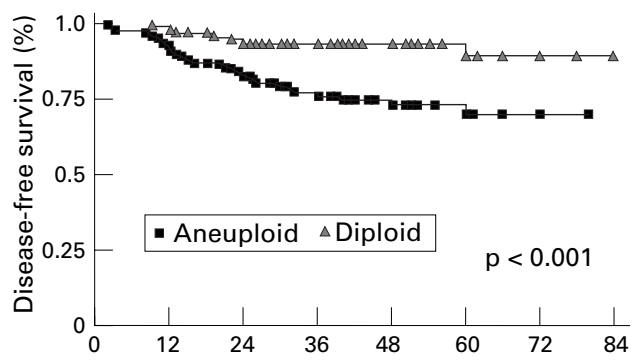

B

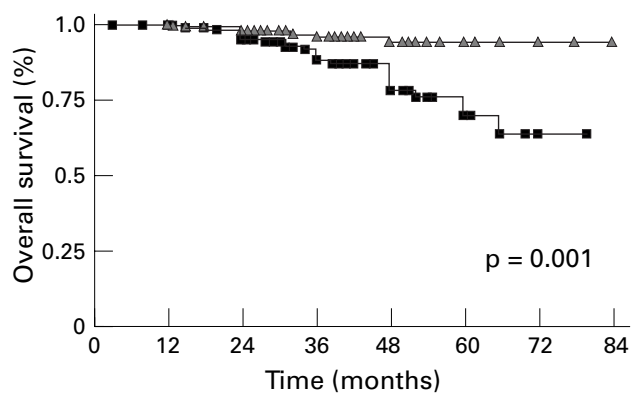

Figure 1 The probability of disease-free survival $(A)$ and overall survival (B) in 308 patients with breast carcinoma according to DNA ploidy (diploid v aneuploid).

HORMONE RECEPTOR EXPRESSION

Oestrogen and progesterone receptors were determined by immunocytochemical analysis on paraffin wax embedded material using the streptavidin-biotin complex peroxidase technique. ${ }^{28}$ Pretreatment procedures included endogenous peroxidase blocking with hydrogen peroxide, and antigen retrieval using a pressure cooker and citrate buffer, $\mathrm{pH} 6.0 .^{29}$ Briefly, the sections were rinsed in Tris buffered saline (TBS), $\mathrm{pH}$ 7.4-7.6, and incubated for 30 minutes at room temperature with primary monoclonal antibody antioestrogen receptor and anti-progesterone re-
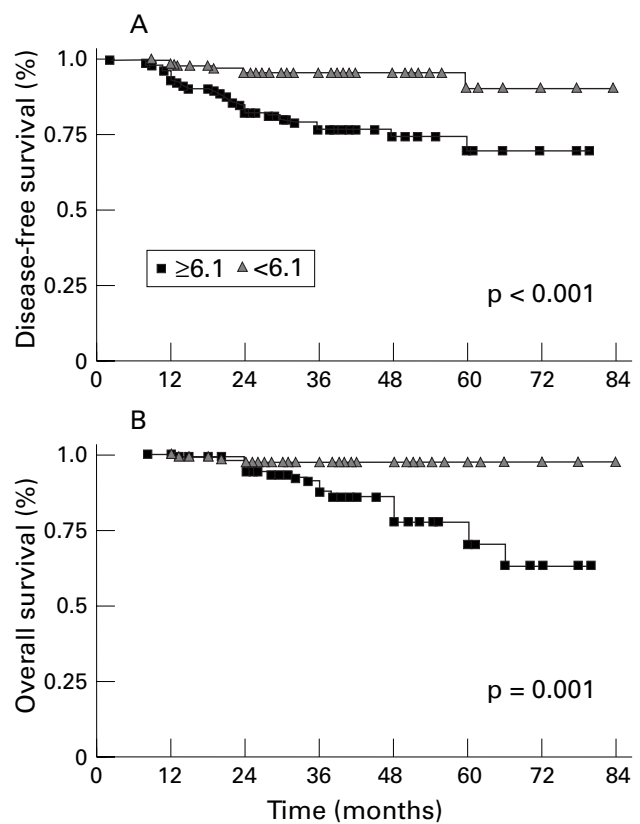

Figure 2 The probability of disease-free survival $(A)$ and overall survival (B) in 238 patients with breast carcinoma according to $S$ phase fraction (low $v$ high). ceptor (NCL-oestrogen receptor-6F11 and NCL-PGR, respectively; Novocastra Laboratories) at a 1:10 dilution. The sections were then washed in TBS and incubated with biotinylated rabbit antimouse serum (E413, Dako) at 1:250 dilution for 30 minutes. The sections were rinsed again in TBS, and StreptABC complex (K377, Dako) at 1:100 dilution was applied for 30 minutes. After washing in TBS, diaminobenzidine was used as chromogen for eight minutes. The sections were then washed in distilled water and counterstained with Mayer's haematoxylin. The results were recorded as the percentage of positively stained target cells, positivity being defined as samples with more than $10 \%$ stained neoplastic cell nuclei.

\section{DNA FLOW CYTOMETRY STUDY}

Flow cytometric analysis was performed on fresh material from specimens obtained at the time of surgery. ${ }^{30}$ Tissue not processed immediately was stored at $-80^{\circ} \mathrm{C}$. The average size of the pieces of tissue used was $0.3 \times 0.3 \mathrm{~cm}$ in their greatest dimensions. In our standard protocol, the tissue samples were mechanically disaggregated using scalpel blades in cold phosphate buffered saline (PBS), and the cell suspension obtained rinsed two times in PBS and checked by counting in a haemocytometer. For DNA staining, the nuclei were incubated with propidium iodide (Sigma), $50 \mu \mathrm{g} / \mathrm{ml}$ in Tris- $\mathrm{MgCl}_{2}$ buffer, for one hour in the dark at $4^{\circ} \mathrm{C}$, treated with RNase (Sigma), $1 \mathrm{mg} / \mathrm{ml}$ in PBS, and $0.05 \%$ Nonidet P40 (Sigma). Immediately before the flow cytometric analysis, the specimens were passed through a 27 gauge needle and then filtered through a $55 \mu \mathrm{m}$ nylon mesh. The stained nuclei were analysed on an Epics Profile II flow cytometer (Coulter Electronics) equipped with a $488 \mathrm{~nm}, 15 \mathrm{~mW}$ argon ion laser as light source and a $575 \mathrm{~nm}$ bandpass filter for red fluorescence detection. The instrument was aligned daily, and considered calibrated when coefficients of variation less than $2 \%$ were obtained with standardised fluorescent beads (DNA-Check, Coulter). Chicken red blood cells were used as an internal control to help the localisation of the $G_{0} / G_{1}$ diploid population, set at channel $50 .{ }^{31}$ Usually, a minimum of 20000 nuclei at a rate of 100-150 per second were acquired for each run, and recorded on a single parameter, 256 channel integrated fluorescence histogram. No electronic gating for discrimination of debris and aggregates was used.

DNA HISTOGRAM INTERPRETATION

Cell cycle analysis of DNA histograms was performed using the Multicycle software program (Phoenix Flow Systems) developed by Peter S Rabinovitch (University of Washington, Seattle, Washington, USA), and based upon the mathematical method described by Dean and Jett. ${ }^{32}$ In order to standardise the analysis, according to previous reproducibility studies $^{33}$ all histograms were fitted to a model that applies zero order S phase fitting and corrections for sliced nuclei debris and aggregates. The coefficient of variation (CV) of tumour 
Table 3 Univariate Cox proportional hazards models of clinicopathological and flow cytometric variables to clinical outcome in breast cancer patients

\begin{tabular}{|c|c|c|c|c|c|c|}
\hline \multirow[b]{2}{*}{ Characteristics } & \multicolumn{3}{|c|}{ Disease-free survival } & \multicolumn{3}{|c|}{ Overall survival } \\
\hline & $\overline{R R}$ & $95 \% C I$ & $p$ Value & $R R$ & $95 \% C I$ & $p$ Value \\
\hline \multicolumn{7}{|l|}{ Age } \\
\hline$<50$ years ${ }^{\star}$ & 1 & - & - & 1 & - & - \\
\hline$\geqslant 50$ years & 0.47 & 0.27 to 0.81 & 0.007 & 0.52 & 0.26 to 1.01 & 0.05 \\
\hline \multicolumn{7}{|l|}{ Grade } \\
\hline $\mathrm{G} 1^{\star}$ & 1 & - & - & & & \\
\hline G2 & 3.57 & 1.37 to 9.30 & 0.009 & & & \\
\hline G3 & 4.99 & 1.87 to 13.31 & 0.001 & & & \\
\hline \multicolumn{7}{|l|}{$\begin{array}{l}\text { Tumour size } \\
\text { (A) }\end{array}$} \\
\hline $\mathrm{pT} 1^{\star}$ & 1 & - & - & & & \\
\hline pT2 & 1.87 & 0.98 to 3.58 & 0.05 & & & \\
\hline pT3 & 2.92 & 1.17 to 7.33 & 0.022 & & & \\
\hline \multicolumn{7}{|c|}{ Tumour size (B) } \\
\hline $\mathrm{pT} 1^{\star}$ & 1 & - & - & 1 & - & - \\
\hline $\mathrm{pT} 2+\mathrm{pT} 3$ & 2.01 & 1.07 to 3.77 & 0.030 & 2.58 & 1.12 to 5.92 & 0.026 \\
\hline \multicolumn{7}{|l|}{ Node status } \\
\hline $\mathrm{pN}^{\star}$ & 1 & - & - & 1 & - & - \\
\hline pN1 & 5.34 & 2.74 to 10.41 & $<0.001$ & 3.92 & 1.82 to 8.44 & $<0.001$ \\
\hline \multicolumn{7}{|c|}{ DNA ploidy (A) } \\
\hline Diploid $^{\star}$ & 1 & - & - & 1 & - & - \\
\hline Aneuploid & 3.61 & 1.81 to 7.22 & $<0.001$ & 3.83 & 1.59 to 9.26 & 0.003 \\
\hline \multicolumn{7}{|c|}{ DNA ploidy (B) } \\
\hline Diploid $\star$ & 1 & - & - & 1 & - & - \\
\hline $\mathrm{hd}+\mathrm{t}$ & 3.46 & 1.71 to 7.03 & 0.001 & 3.26 & 1.31 to 8.13 & 0.011 \\
\hline $\mathrm{m}+\mathrm{ht}$ & 4.42 & 1.74 to 11.19 & 0.002 & 6.74 & 2.34 to 19.43 & $<0.001$ \\
\hline \multicolumn{7}{|l|}{ SPF } \\
\hline$<6.1 \%{ }^{\star}$ & 1 & - & - & & & \\
\hline$\geqslant 6.1 \%$ & 4.45 & 1.94 to 10.18 & $<0.001$ & & & \\
\hline \multicolumn{7}{|c|}{ Oestrogen receptors } \\
\hline Positive ${ }^{\star}$ & 1 & - & - & 1 & - & - \\
\hline Negative & 1.84 & 1.03 to 3.28 & 0.038 & 2.04 & 1.02 to 4.11 & 0.045 \\
\hline \multicolumn{7}{|c|}{ Progesterone receptors } \\
\hline Positive ${ }^{\star}$ & 1 & - & - & 1 & - & - \\
\hline Negative & 1.87 & 1.07 to 3.25 & 0.027 & 2.24 & 1.12 to 4.48 & 0.022 \\
\hline
\end{tabular}

$\mathrm{CI}$, confidence interval; $\mathrm{hd}+\mathrm{t}$, hyperdiploid + tetraploid; $\mathrm{m}+\mathrm{ht}$, multiploid + hypertetraploid; $\mathrm{RR}$, relative risk; $\mathrm{SPF}, \mathrm{S}$ phase fraction.

${ }^{\star}$ Reference category.

$\mathrm{G}_{0} / \mathrm{G}_{1}$ peaks, estimated as half peak width, ranged from 2.4 to 7.8 (mean 4.2). Histograms with CVs over $8 \%$ were not included in the study. ${ }^{34}$ The DNA ploidy pattern was expressed by the DNA index (DI) - that is, the ratio between the mean fluorescence channel number of the tumour $\mathrm{G}_{0} / \mathrm{G}_{1}$ peak and that of the diploid $G_{0} / G_{1}$ reference peak. Mixed non-malignant diploid cells from the same tumour sample analysed-namely fibroblasts, lymphocytes, and normal epithelial cells-were regarded as an internal standard.

The tumours were classified into five categories in relation to DNA ploidy: a tumour showing a single peak with DNA index $=0.95-1.05$ was classified as DNA diploid; if an additional peak was present, the tumour was considered in one of the four DNA aneuploid categories based on DNA index. Thus the tumour was considered as hyperdiploid in the DNA index range 1.05-1.92, as tetraploid in the range

Table 4 Cox regression multivariate analysis of breast cancer patients

\begin{tabular}{|c|c|c|c|c|c|c|}
\hline \multirow[b]{2}{*}{ Characteristics } & \multicolumn{3}{|c|}{ Disease-free survival } & \multicolumn{3}{|c|}{ Overall survival } \\
\hline & $R R$ & $95 \% C I$ & $p$ Value & $R R$ & $95 \% C I$ & $p$ Value \\
\hline \multicolumn{7}{|l|}{ Node status } \\
\hline $\mathrm{pN} 0^{\star}$ & 1 & - & - & 1 & - & - \\
\hline pN1 & 4.90 & 2.29 to 10.47 & $<0.001$ & 3.59 & 1.66 to 7.78 & 0.001 \\
\hline \multicolumn{7}{|l|}{ DNA ploidy } \\
\hline Diploid $\star$ & & & & 1 & - & - \\
\hline Aneuploid & & & & 3.43 & 1.42 to 8.29 & 0.006 \\
\hline \multicolumn{7}{|l|}{ SPF } \\
\hline$<6.1 \%{ }^{\star}$ & 1 & - & - & & & \\
\hline$\geqslant 6.1 \%$ & 4.53 & 1.98 to 10.39 & $<0.001$ & & & \\
\hline
\end{tabular}

$\mathrm{CI}$, confidence interval; RR, relative risk; SPF, S phase fraction.

${ }^{\star}$ Reference category.
$1.92-2.04$ (with at least $20 \%$ of total cell count and a corresponding $\mathrm{G}_{2} \mathrm{M}$ peak), and as hypertetraploid in the range above 2.04. If more than one aneuploid peak was observed the tumour was classified as multiploid. To define the DNA tetraploidy range of tumours, we calculated the ratio between the mean channel number of the $G_{2} M$ peak and that of the respective $G_{0} / G_{1}$ peak of 100 consecutive diploid breast tumours, which was 1.98 (0.06) (mean (SD)).

The $S$ phase fraction (SPF) - a measure of tumour proliferative activity-was determined from the histogram according to the polynomial model, ${ }^{36}$ as the percentage of cells in the $S$ phase of the cycle, and could be calculated in 238 cases $(77.3 \%)$. In the remaining 70 tumours $(22.7 \%)$, all but four being DNA aneuploid, SPF determination could not be reliably assessed for any of the following reasons: the samples had a high degree of background debris (critical percentage $>20 \%)$; there was a small $(<15 \%)$ but undoubtedly non-diploid population; the $\mathrm{CV}$ of the $G_{0} / G_{1}$ peak was too large in an unequivocally aneuploid population; there was a clear overlap of two populations (near diploidy); or the tumours were classified as DNA multiploid or in some cases as DNA hypertetraploid. In aneuploid cases, SPF was calculated for the aneuploid population only.

\section{STATISTICAL ANALYSIS}

The correlations between the flow cytometric variables and clinicopathological features were assessed using the $\chi^{2}$ test or Fisher's exact test when biomarkers were used as dichotomous variables. The Mann-Whitney test or the Kruskal-Wallis test were applied when biomarkers, as continuous variables, did not show a gaussian distribution. Student's $t$ test was used to compare mean values among groups. The cumulative probability of disease-free and overall survival after surgical resection was estimated according to the Kaplan-Meier method. ${ }^{35}$ The differences between the survival curves were analysed by the log-rank test. ${ }^{36}$ To determine the relative predictive strength of the prognostic variables, a Cox proportional hazards regression model was used. ${ }^{37}$ The statistical significance was evaluated using the Wald test and results were displayed as relative risk and respective 95\% confidence intervals for each category. Probability (p) values less than 0.05 were considered significant.

\section{Results}

\section{DNA ANALYSIS}

Of the 308 breast tumours analysed by flow cytometry, $134(43.5 \%)$ showed a DNA diploid pattern, and $174(56.5 \%)$ were DNA aneuploid. In the latter group, 128 tumours $(41.6 \%)$ were simple DNA hyperdiploid, 17 (5.5\%) were DNA tetraploid, 15 (4.9\%) were simple DNA hypertetraploid, and $14(4.6 \%)$ were DNA multiploid. Nine multiploid tumours had a hypertetraploid population; thus there was a total of 24 hypertetraploid tumours $(7.8 \%)$ in this series.

The median SPF of the tumours ( $n=238$ ) in which the SPF determination was feasible 
Table 5 Five year disease-free survival according to cytometric indices in lymph node negative ( $p N 0)$ and lymph node positive ( $p N 1)$ patient categories

\begin{tabular}{|c|c|c|c|c|c|c|}
\hline \multirow[b]{2}{*}{ Variable } & \multicolumn{3}{|c|}{ pNO } & \multicolumn{3}{|c|}{$p N 1$} \\
\hline & $n$ & $\% 5$ years $(S D)$ & $p$ Value & $n$ & $\% 5$ years $(S D)$ & $p$ Value \\
\hline DNA ploidy & & & NS & & & 0.0009 \\
\hline Diploid & 86 & $89.0(0.07)$ & & 48 & $87.3(0.05)$ & \\
\hline Aneuploid & 89 & $85.9(0.07)$ & & 85 & $54.0(0.06)$ & \\
\hline SPF & & & NS & & & 0.0006 \\
\hline$<6.1 \%$ & 73 & $89.6(0.89)$ & & 45 & $88.7(0.05)$ & \\
\hline$\geqslant 6.1 \%$ & 69 & $82.5(0.08)$ & & 51 & $51.5(0.09)$ & \\
\hline
\end{tabular}

SPF, $\mathrm{S}$ phase fraction.

Table 6 Five year overall survival according to cytometric variables in lymph node negative ( $p N 0)$ and lymph node positive ( $p N 1$ ) patient categories

\begin{tabular}{|c|c|c|c|c|c|c|}
\hline \multirow[b]{2}{*}{ Variable } & \multicolumn{3}{|c|}{ pNO } & \multicolumn{3}{|c|}{$p N 1$} \\
\hline & $n$ & $\% 5$ years $(S D)$ & $p$ Value & $n$ & $\% 5$ years $(S D)$ & $p$ Value \\
\hline DNA ploidy & & & NS & & & 0.0048 \\
\hline Diploid & 86 & $94.3(0.04)$ & & 48 & $92.7(0.04)$ & \\
\hline Aneuploid & 89 & $88.1(0.05)$ & & 85 & $51.3(0.10)$ & \\
\hline SPF & & & NS & & & 0.0021 \\
\hline$<6.1 \%$ & 73 & $98.6(0.001)$ & & 45 & $95.4(0.03)$ & \\
\hline$\geqslant 6.1 \%$ & 69 & $85.2(0.006)$ & & 51 & $48.4(0.13)$ & \\
\hline
\end{tabular}

SPF, S phase fraction.

was $6.1 \%$ (mean $7.7 \%$ ), ranging from $1 \%$ to $27.8 \%$. The median value was considered as the cut off point that discriminated between tumours with high proliferative activity $(\geqslant 6.1 \%)$ and tumours with low proliferative activity $(<6.1 \%)$. One hundred and thirteen of 117 low SPF tumours (96.6\%) were DNA diploid, while 104 of 121 with high SPF $(86.0 \%)$ were DNA aneuploid. The median SPF value of the DNA aneuploid tumours $(12.0 \%$; range $3.7 \%$ to $27.8 \%$ ) was found to be significantly higher than that of the DNA diploid tumours (3.8\%; range $1 \%$ to $12.0 \%$ ) $(\mathrm{p}<0.001)$.

HORMONE RECEPTOR ANALYSIS

Hormone receptor determination was performed in all but one case which lacked
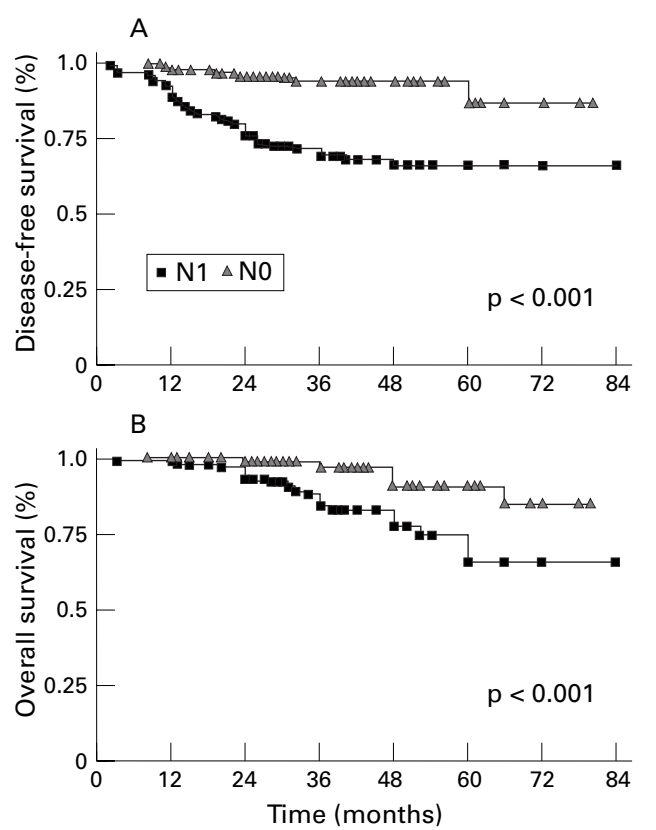

Figure 3 The probability of disease-free survival $(A)$ and overall survival $(B)$ of 308 patients with breast carcinoma according to lymph node status ( $p N 0 v p N 1$ ). representative material $(n=307)$. Tumours were positive for oestrogen receptors and progesterone receptors in $229(74.6 \%)$ and 188 $(61.2 \%)$, respectively. DNA aneuploidy was more often found to be associated with oestrogen receptor negative and progesterone receptor negative tumours $(82.1 \%$ and $74.0 \%$, respectively), and this was also true for high SPF $(82.7 \%$ and $70.4 \%$, respectively) (table 1$)$.

\section{CORRELATION WITH OTHER PROGNOSTIC}

FACTORS

Table 1 shows the correlations between the flow cytometric variables and the clinicopathological characteristics evaluated. DNA aneuploid tumours and tumours with high proliferative activity were associated with invasive ductal carcinomas of greater size, with poor differentiation, and lack of hormone receptor activity. DNA ploidy was also associated with node status, whereas SPF was not. No correlation was found between either DNA ploidy or SPF and patients' age.

SURVIVAL ANALYSIS

The median follow up time was 39.6 months (range 3 to 84 ). At the end of the follow up period, 256 patients $(83.1 \%)$ were alive without evidence of disease, $17(5.5 \%)$ were alive with disease, and $34(11.1 \%)$ had died of their disease. Table 2 summarises the five year survival rates of the patients for each of the characteristics studied. The disease-free and overall survival for all patients at five years was $78.0 \%$ and $79.8 \%$, respectively. The corresponding figures for patients with DNA diploid tumours were $88.5 \%$ and $93.8 \%$, and for patients with DNA aneuploid tumours, $69.5 \%$ and $69.9 \%$ (fig 1). Patients with tumours with low proliferative activity also had better disease-free survival and overall survival $(86.4 \%$ and $93.0 \%$, respectively) compared with those with high proliferative activity $(69.2 \%$ and $70.9 \%)$ (fig 2).

Table 3 shows the association between the various clinicopathological and flow cytometric variables and survival in a univariate analysis. Age ( $<50$ years $v \geqslant 50$ years), histological grade, tumour size, node involvement, DNA ploidy, SPF, and hormone receptors were significant indicators of disease-free survival, while age, tumour size (pT1 v pT2+pT3), node status, DNA ploidy, and hormone receptors were significant predictors of overall survival. In multivariate analysis, as shown in table 4, axillary lymph node status and DNA ploidy retained independent prognostic value in relation to overall survival $(\mathrm{p}=0.001$ and $\mathrm{p}=0.006$, respectively), while node status $(\mathrm{p}<0.001)$ and SPF $(\mathrm{p}<0.001)$ were statistically significant in disease-free survival.

We also examined the prognostic impact of DNA ploidy and SPF in the subgroups of patients with ( $\mathrm{pN} 1$ ) and without ( $\mathrm{pN} 0)$ axillary lymph node involvement for either disease-free survival (table 5) or overall survival (table 6). While the cytometric variables were found to be statistically significant in the lymph node positive subgroup, no significance was observed in the other subgroup. However, when 
SPF was treated as a continuous variable to investigate its relative prognostic strength, it showed a statistically significant predictive value in the lymph node negative subgroup for either disease-free survival (relative risk 1.13; $\mathrm{p}=0.019$ ) or overall survival (relative risk $1.33 ; \mathrm{p}=0.004)$.

\section{Discussion}

This study confirms the importance of the axillary node status in the outcome evaluation of breast carcinoma. Our data showed that this is the single most relevant prognosticator of disease-free and overall survival: $91.0 \%$ of the node negative patients were alive five years after surgery, in contrast to $65.7 \%$ of the node positive patients (fig 3), confirming previous data. . $^{4} 910132038-40$

In contrast, the prognostic significance of flow cytometric biomarkers - that is, DNA ploidy and SPF-in breast cancer is still controversial. The disagreement between groups of investigators is generally related to the lack of standardised methodological approaches in relation to either the sampling procedures or the analysis of the results. ${ }^{22534}$ Another reason that has been advocated to explain the conflicting results in published reports is the intratumour heterogeneity found in breast cancer for DNA ploidy and cell cycle variables $^{23}{ }^{24}$; for example, Bergers et al showed that at least six samples may have to be prepared and measured separately for suitable detection of DNA aneuploidy. ${ }^{24}$

The rationale for the subclassification of tumours according to DNA ploidy is that the prognostic power can be improved and more aggressive treatment adopted. ${ }^{41}$ Most investigators have claimed a small survival advantage for diploid $v$ aneuploid breast carcinomas. ${ }^{5} 710254042$ In contrast, other investigators have found no significant prognostic impact on tumour ploidy. ${ }^{18-21}$ In our study, DNA ploidy was shown to be the second most important and independently significant prognostic factor in relation to overall survival. Like us, most other investigators have reported that DNA ploidy has prognostic importance, ${ }^{4-1140} 42$ although only a few have proven its independent value. ${ }^{4-9}$ Our data also revealed that within the DNA aneuploidy group (table 2), the subset of patients with DNA multiploid/hypertetraploid tumours had the worst clinical outcome ( $54.7 \%$ were alive five years after surgery), with a relative risk of cancer related death of 6.74 (table 3), in accordance with previously reported studies. ${ }^{67910212543}$ This finding may have clinical value in relation to the selection of more aggressive treatment, although it should be noted that this subgroup of patients is very small ( $\mathrm{n}=27)$, and thus the survival rates may be affected by sampling error.

Most studies have shown a strong correlation between high SPF and increased risk of recurrence and mortality in patients with breast carcinoma. ${ }^{671011-1725}$ Camplejohn et al studied 881 patients treated in a single centre and showed that SPF was a robust predictor of clinical outcome in terms of overall survival, relapse-free survival, and survival after relapse..$^{10}$ Sigurdsson et al also concluded that SPF yielded the most relevant prognostic information in their study of 367 women with node negative breast cancer. ${ }^{11}$ In contrast, Stanton et $a l^{20}$ and Silvestrini et $a l^{44}$ failed to demonstrate such associations, even in a univariate analysis study. We found that SPF had independent prognostic value in relation to disease-free survival. With regard to overall survival, SPF did not show a statistically significant association since, in statistical terms, it did not verify Hazard's function proportionality in the Cox regression model used. This appears to be related to the fact that patients with highly proliferative tumours have a better short term clinical response after postsurgical chemotherapy than those with low proliferative activity, but this is followed by dramatic long term clinical failure (fig 2B). This view is largely supported by the studies of Remvikos et al concerning the interaction between tumour proliferative activity and neoadjuvant treatment. ${ }^{165} \mathrm{~A}$ similar finding was observed when DNA ploidy was associated with disease-free survival in multivariate analysis, losing its univariate statistical significance because of the higher comparatively strength of SPF. Thus the existence of a very close relation between the two flow cytometric variables was not surprising. In fact, $96.6 \%$ of tumours with low proliferative activity were DNA diploid, while $86.0 \%$ of tumours with high proliferative activity were DNA aneuploid. Interestingly, three of 17 patients with DNA diploid tumours with high SPF died of the disease, while three of four patients with DNA aneuploid tumours with low SPF were alive without evidence of disease at the time of writing. Most previous reports also showed that DNA aneuploid tumours typically have a significantly higher SPF than DNA diploid tumours. ${ }^{6} 7101114182546$

We also investigated the independent prognostic significance of DNA ploidy and SPF in lymph node negative and lymph node positive subgroups (tables 5 and 6). A strongly significant influence was present in the lymph node positive subgroup for both variables in relation to either disease-free survival or overall survival. In contrast, and in keeping with previous studies, ${ }^{11} 12^{1541}$ neither DNA flow cytometry nor any of the other clinicopathological characteristics analysed in this study (data not shown) were correlated with prognosis in the lymph node negative subgroup. However, when SPF was evaluated as a continuous variable it reached statistical significance as a prognostic indicator, thus confirming its overall clinical importance.

We observed a statistically significant correlation between both DNA ploidy and SPF and various histopathological characteristics known to affect disease prognosis (table 1). DNA aneuploid tumours or tumours with high proliferative activity were more likely to be associated with invasive ductal histology, larger size, poor differentiation, and lack of hormone receptor expression. Some other investigators have shown similar correlations, for example with tumour size, ${ }^{581421}$ grade of differentiation, ${ }^{6} 8192147$ and presence of endo- 
crine receptors. ${ }^{6} 9144446$ In our study we should stress the predominance of DNA diploid tumours $(28 / 33 ; 84.8 \%)$ among the histological subtypes other than invasive ductal breast carcinoma, which is consistent with their generally favourable outcome. Our results also showed no association between either of the flow cytometric variables and the patients' age, as in previously reported studies. ${ }^{8} 9141946$ The lack of correlation between SPF and node involvement was notable; this may reflect the different biological significance of these two characteristics in breast cancer disease despite the similar impact on the clinical behaviour of tumours.

In univariate analysis (table 3), tumour size and grade of differentiation were statistically significant predictors of disease-free survival, the former also being predictive of overall survival when the dichotomy pT1 $v$ pT2+pT 3 was used for tumour classification, which is in agreement with previous reports. ${ }^{689121317}$ Witzig et al showed that tumour size was the most significant factor in the multivariate analysis of 265 node negative breast carcinomas. ${ }^{15}$ Elston and Ellis ${ }^{27}$ assessed the histological grade in 1831 patients and found a very strong correlation with prognosis. However, difficulties in the reproducibility of these factors owing to the subjective nature of their assessment decreases their potential prognostic value. In keeping with other studies, ${ }^{4} 61148$ hormone receptor status was found to be a predictive feature, although the published data are not in overall agreement about its prognostic significance. ${ }^{170}$ This may in part be related to the strong association between receptor status and other prognostic factors which could be responsible for the prognostic value inherent in receptor determinations. ${ }^{49}$ Nevertheless, hormone receptor analysis is considered to be useful in predicting the response after adjuvant antioestrogen treatment. ${ }^{1450}$ Patients' age ( $<50$ years $v \geqslant 50$ years), used as a rough indicator of the menopausal status, was also found to be predictive in univariate analysis, especially in relation to disease-free survival. Our finding corroborates the view that breast carcinoma has a lower incidence among younger patients but is often more aggressive and has a worse clinical outcome..$^{52}$

It is well known that there are at least two subgroups of breast cancer patients which investigators seek to identify. ${ }^{53}$ One of these includes a minority of better survivors in a poor prognosis group; the other comprises patients with disease recurrence or death in a good prognosis group. The cumulative evidence, and our present data, indicate that DNA ploidy and SPF can provide additional prognostic information on the biological behaviour of breast carcinomas, and can therefore help in the identification of low risk and high risk subgroups. This allows better stratification of individual patients for appropriate treatment. Furthermore, DNA ploidy and SPF are readily determined by rapid and automated flow cytometry. The main limitations on the clinical use of this biological information are related to technical difficulties in the accurate determination of
SPF in about $17-27 \%$ of the DNA histograms $(22.7 \%$ in our series $),{ }^{7} 1018$ and the lack of consensual criteria to define cut off points to discriminate between tumours with low and high proliferative activity for prognostic purposes. ${ }^{714182254}$

\section{CONCLUSIONS}

Our findings showed that, providing fresh/ frozen tissue is used as sample material and that there are adequate criteria for the histogram interpretation of DNA flow cytometry analysis, DNA ploidy and SPF are useful biomarkers for the management of patients with invasive breast cancer, and only marginally inferior to axillary lymph node status in their relative importance in predicting disease outcome.

This study was supported in part by the grant "Programa de Investigação em Oncologia 1998-2001" from Liga Portuguesa Contra o Cancro-Núcleo Regional do Sul. The excellent technical assistance of Mrs Teresa Pereira in immunocytochemistry and flow cytometry work is gratefully acknowledged. We also and flow cytometry work is gratefully acknowledged. We also
thank Dr Sónia Dória and Dr Susana Segão for valuable comments on the statistical analysis.

1 McGuire WL, Clark GM. Prognostic factors and treatment decisions in axillary node-negative breast cancer. $N$ Engl F Med 1992;326:1756-61.

2 Gasparini G, Pozza F, Harris AL. Evaluating the potential usefulness of new prognostic and predictive indicators in node-negative breast cancer patients. 7 Natl Cancer Inst 1993;85:1206-19.

3 Mansour EG, Ravdin PM, Dressler L. Prognostic factors in Mansour EG, Ravdin PM, Dressler L. Prognostic

4 Kallioniemi OP, Blanco G, Alavaikko M, et al. Tumour Kallioniemi OP, Blanco G, Alavaikko $\mathrm{M}$, et al. Tumour
DNA ploidy as an independent prognostic factor in breast DNA ploidy as an independent progn

Cancer. Br F Cancer 1987;56:637-42.
Cornelisse CJ, van de Velde CJ, Caspers RJ, et al. DNA ploidy and survival in breast cancer patients. Cytometry 1987;8:225-34.

6 Kallioniemi O, Blanco G, Alavaikko M, et al. Improving the prognostic value of DNA flow cytometry in breast cancer by combining DNA index and S-phase fraction. A cancer. Cancer 1988;62:2183-90.

7 Clark GM, Dressler LG, Owens MA, et al. Prediction of relapse or survival in patients with node-negative breast cancer by DNA flow cytometry. N Engl f Med 1989;320: 627-33.

8 Lewis WE. Prognostic significance of flow cytometric DNA analysis in node-negative breast cancer patients. Cancer 990;65:2315-20.

9 Beerman H, Kluin PM, Hermans J, et al. Prognostic significance of DNA-ploidy in a series of 690 primary breast cancer patients. Int $\mathcal{F}$ Cancer 1990;45:34-9.

10 Camplejohn RS, Ash CM, Gillett CE, et al. The prognostic significance of DNA flow cytometry in breast cancer: results from 881 patients treated in a single centre. $\mathrm{Br} \mathcal{F}$ Cancer 1995;71:140-5.

11 Sigurdsson H, Baldetorp B, Borg Å, et al. Indicators of prognosis in node-negative breast cancer. $N$ Engl f Med 1990;322:1045-53.

12 Clark GM, Mathieu M-C, Owens MA, et al. Prognostic significance of S-phase fraction in good-risk, node-negative breast cancer patients. F Clin Oncol 1992;10:428-32.

13 Joensuu H, Alanen K, Falkmer UG, et al. Effect of DNA ploidy classification on prognosis in breast cancer. Int $\mathcal{F}$ 1992;52:701-6.

14 Stål O, Dufmats M, Hatschek T, et al. S-phase fraction is a prognostic factor in stage I breast carcinoma. $\mathcal{F}$ Clin Oncol 1993;11:1717-22.

15 Witzig TE, Ingle JN, Cha SS, et al. DNA ploidy and the percentage of cells in S-phase as prognostic factors for women with lymph node negative breast cancer. Cancer 1994;74:1752-61.

16 Remvikos Y, Mosseri V, Asselain B, et al. S-phase fractions of breast cancer predict overall and post-relapse survival. Eur F Cancer 1997;33:581-6.

17 Peiró G, Lerma E, Climent MA, et al. Prognostic value of $\mathrm{S}$-phase fraction in lymph node-negative breast cancer by image and flow cytometric analysis. Mod Pathol 1997;10: 216-22.

18 Muss HB, Kute TE, Case LD, et al. The relation of flow cytometry to clinical and biologic characteristics in women with node negative primary breast cancer. Cancer 1989;64: 1894-900.

19 Keyhani-Rofagha S, O'Toole RV, Farrar WB, et al. Is DNA ploidy an independent prognostic indicator in infiltrative node-negative breast adenocarcinoma? Cancer 1990;65: node-negativ

20 Stanton PD, Cooke TG, Oakes SJ, et al. Lack of prognostic significance of DNA ploidy and S-phase fraction in breast cancer. Br f Cancer 1992;66:925-9. 
21 Bosari S, Lee AKC, Tahan SR, et al. DNA flow cytometric analysis and prognosis of axillary lymph node-negative

22 Baldetorp B, Bendahl P-O, Fernö M, et al. Reproducibility in DNA flow cytometric analysis of breast cancer: comparison of 12 laboratories' results for 67 sample homogenates. Cytometry (Commun Clin Cytometry) 1995; 22:115-27.

23 Schvimer M, Lash RH, Katzin WE. Intratumoral heterogeneity of DNA ploidy in breast carcinomas: a flow cytometric assessment of sampling techniques. Cytometry (Commun Clin Cytometry) 1995;22:292-6.

24 Bergers E, van Diest PJ, Baak JPA. Tumour heterogeneity of DNA cell cycle variables in breast cancer measured by flow cytometry. F Clin Pathol 1996;49:931-7.

25 Hedley DW, Clark GM, Cornelisse CJ, et al. Consensus review of the clinical utility of DNA cytometry in carcinoma of the breast. Cytometry 1993;14:482-5.

26 Beahrs OH, Henson DE, Hutter RVP, et al. Manual for staging of cancer, 5th ed. Philadelphia: JB Lippincott, 1997: ing of canc $171-80$.

27 Elston CW, Ellis IO. Pathological prognostic factors in breast cancer. I. The value of histological grade in breast cancer: experience from a large study with long-term 1991:19:403-10.

28 Hsu SM, Raine L, Fanger H. The use of antiavidin antibody and avidin-biotin-peroxidase complex in immunoperoxidase technics. Am $\mathcal{f}$ Clin Pathol 1981;75:816-21.

29 Norton AJ, Jordan S, Yeomans P. Brief, high-temperature heat denaturation (pressure cooking): a simple and effective method of antigen retrieval for routinely processed tissues. F Pathol 1994;173:371-9.

30 Deitch AD, Law $\mathrm{H}$, White RD. A stable propidium iodide staining procedure for flow cytometry. If Histochem Cytochem 1982;30:967-72.

31 Vindeløv LL, Christensson IJ, Nissen NI. Standardization of high-resolution flow cytometric DNA analyses by simultaneous use of chicken and trout red blood cells as internal taneous use of chicken and trout red blood cells
reference standards. Cytometry 1983;3:328-31.

32 Dean PN, Jett JH. Mathematical analysis of DNA distributions derived from flow microfluorometry. 7 Cell Biol 1974 tions derived.

33 Bergers E, Montironi R, van Diest PJ, et al. Interlaboratory reproducibility of semiautomated cell cycle analysis of flow cytometric DNA-histograms obtained from fresh materia of 1,295 breast cancer cases. Hum Pathol 1996;27:553-60.

34 Shankey TV, Rabinovitch PS, Bagwell B, et al. Guidelines for implementation of clinical DNA cytometry. Cytometry 1993;14:472-7.

35 Kaplan EL, Meier P. Nonparametric estimation from incomplete observations. F Am Stat Assoc 1958;53:457-81.

36 Mantel N. Evaluation of survival data and two new rank order statistics arising in its consideration. Cancer Chemother Rep 1966;50:163-70.

37 Cox DR. Regression models and life tables. F R Stat Soc B 1972;34:187-220.

38 Rosen PP, Saigo PE, Braun DW, et al. Predictors of recurrence in stage I $\left(\mathrm{T}_{1} \mathrm{~N}_{0} \mathrm{M}_{0}\right)$ breast carcinoma. Ann Surg 1981:193:15-25.
39 Carter CL, Allen C, Henson DE. Relation of tumor size, lymph node status, and survival in 24,740 breast cancer cases. Cancer 1989;63:181-7.

40 Uyterlinde AM, Baak JPA, Schipper NW, et al. Further evaluation of the prognostic value of morphometric and flow cytometric parameters in breast-cancer patients with long follow-up. Int $\mathcal{F}$ Cancer 1990;45:1-7.

41 Bergers E, Baak JPA, van Diest PJ, et al. Prognostic value of DNA ploidy using flow cytometry in 1301 breast cancer patients: results of the prospective multicenter morphometric mammary carcinoma project. Mod Pathol 1997;10:7628.

42 O'Reilly SM, Richards MA. Is DNA flow cytometry a useful investigation in breast cancer? Eur $\mathcal{F}$ Cancer 1992;28 504-7.

43 Pinto AE, André S, Nogueira M, et al. Flow cytometric DNA hypertetraploidy is associated with unfavourable prognostic features in breast cancer. F Clin Pathol 1997;50: 591-5.

44 Silvestrini R, Daidone MG, Del Bino G, et al. Prognostic significance of proliferative activity and ploidy in nodenegative breast cancers. Ann Oncol 1993;4:213-19.

45 Remvikos Y, Beuzeboc P, Zajdela A, et al. Correlation of pretreatment proliferative activity of breast cancer with the response to cytotoxic chemotherapy. $\mathcal{f}$ Natl Cancer Inst 1989;81:1383-7.

46 Dressler LG, Seamer LC, Owens MA, et al. DNA flow cytometry and prognostic factors in 1331 frozen breast cancer specimens. Cancer 1988;61:420-7.

47 Frierson HF. Grade and flow cytometric analysis of ploidy for infiltrating ductal carcinomas. Hum Pathol 1993;24:24-

48 Hupperets PS, Volovics L, Schouten HC, et al. The prognostic significance of steroid receptor activity in tumor tissues of patients with primary breast cancer. Am $\mathcal{F}$ Clin Oncol 1997;20:546-51.

49 Thorpe SM. Estrogen and progesterone receptor determinations in breast cancer: technology, biology and clinical significance. Acta Oncol 1988;27:1-19.

50 Neville AM, Bettelheim R, Gelber RD, et al, for the International (Ludwig) Breast Cancer Study Group. Factors predicting treatment responsiveness and prognosis in node-negative breast cancer. $\mathcal{F}$ Clin Oncol 1992;10:696705.

51 Høst $\mathrm{H}$, Lund $\mathrm{E}$. Age as a prognostic factor in breast cancer. Cancer 1986;57:2217-21.

52 Nixon AJ, Neuberg D, Hayes DF, et al. Relationship of patient age to pathologic features of the tumor and prognosis for patients with stage I or II breast cancer. F Clin Oncol 1994;12:888-94.

53 Page DL. Prognosis and breast cancer: recognition of lethal and favorable prognostic types. Am f Surg Pathol 1991;15: 334-49.

54 Sigurdsson H, Baldetorp B, Borg A, et al. Flow cytometry in primary breast cancer: improving the prognostic value of the fraction of cells in the S-phase by optimal categorizathe fraction of cells in the S-phase by optimal categc
tion of cut-off levels. Br f Cancer 1990;62:786-90. 